\title{
Modernitet og sekularisme i krise
}

\section{Lailufar Yasmin}

\section{Tyrkiet, Egypten og Bangladesh er eksempler på eliter, der følger Vestens begreb om sekularise- ring, mens befolkningerne vil kombinere moder- nitet og islam}

Hver gang et demokratisk rum er åbnet, har mennesker været ivrige efter at vælge dem, som tilbyder bedre løsninger på deres økonomiske og sociale problemer, men som samtidig kan tilbyde dem anerkendelse af deres kulturers bæredygtige karakterer.

Forestillingen, at Vesten har en civiliserende mission over for resten af verden, beror på den gængse opfattelse af modernitet som adskillelse af religion og den offentlige sfære. Denne mission har til formål at påføre islamiske lande en simpel opfattelse af modernitet, der overser de ikke-vestlige landes differentierede erfaringer og opfattelser, lige så vel som den overser de differentierede erfaringer med modernitet inden for Vesten.

Religion bliver således den afgørende faktor for, hvem der er moderne og hvem ikke, og følgelig hvem der er civiliseret og hvem ikke.

En sådan synsvinkel hævder, at der er en 'organisk' forbindelse mellem modernisering og sekularisering, som Vesten har været bærer af i halvandet århundrede. Dette tenderer til at være farlig binært og udsondre resten af verden, især lande med muslimsk flertal, som uciviliserede medlemmer af det internationale samfund.

Jeg vil her argumentere for, at masserne i lande med muslimsk flertal har afvist en sådan opfattelse og $\mathrm{i}$ stedet støtter islamister, som har et alternativt perspektiv, der indebærer blanding af modernitet og islam.

Det er eliterne i Tyrkiet, Egypten og Bangladesh, der er imod en sådan forståelse, og i stedet tenderer til at replicere den vestlige konstruktion af religion, at islam er en forhindring for modernitet.

Det har kun åbnet vejen for flere 
uproduktive spændinger i disse lande.

Det moderne Vesten har gjort sig selv distinkt fra resten af verden ved at skille den verdslige og åndelige verden fra hinanden. Denne adskillelse er ifølge Charles Taylor "Vestens store opfindelse".

\section{Sekularisme}

Reformationer i Europa i det 16. til 18. århundrede banede vejen for humanismens opblomstring og en moderne opfattelse af verden, som er udpræget sekulær.

Sekularisme ses som henvisning af religiøsitet til livets privatsfære. Begrebet blev oprindeligt introduceret af George Jacob Hollyake i 1851 som en måde at skabe en klar forskel mellem en sekulær angrebsvinkel til religion som del af ens privatliv, og ateisme. Termen blev ofte brugt til det formål i slutningen af det 19. århundrede.

Distinktionen mellem ateisme og sekularisme opstod af frygt for, at støtte til en sekulær offentlighed ville blive misforstået som bekendelse til udryddelse af religion, som var det modsatte af den kantianske dagsorden for det sekulære. Den fremstående teoretiker for det sekulære definerede en skarp grænse mellem den private og den offentlige sfære.

Immanuel Kant insisterede på, at det ikke ville være enden på religion at gøre den offentlige sfære sekulær, og han havde bestemt ikke noget imod religion i menneskers privat- sfære. Kant insisterede i stedet på, at tro på en suveræn gud krænkede menneskelig autonomi og frihed.

Modernitet blev således opfattet, som om den ville begrænse religionens rolle i det offentlige rum til fordel for fornuft og videnskab. Det var en central opfattelse i teorier af John Locke, Emile Durkheim, Max Weber, Karl Marx og Friedrich Engels, for at nævne enkelte. På den ene eller anden måde mente fortalerne for denne skole, at religion var menneskers privatsag.

Selv om få sagde det eksplicit, var en yderlige implikation af denne tænkning, at religion var nogle reminiscenser fra 'mørkets tidsalder', som 'snart ville forsvinde', og at sekularisering var grundlæggende progressiv.

Men denne opfattelse fra tidligt i det 20. århundrede ændredes dramatisk i 1960'erne og 70'erne med starten på studier i Vesten som 'historie nedefra'.

Den forudsete afslutning på religion i moderne samfund blev udfordret af beviserne på livlig religionsudøvelse i hverdagslivet. Siden førte religionens øgede synlighed i Vesten til opfattelsen sent i det 20. århundrede, at der var sket en 'tilbagevenden' for religion i vestlige samfund.

\section{Muslimsk dilemma}

Fremvæksten af nationalstaten og dens fortsættelse i moderne form er direkte forbundet med en adskillel- 
se imellem religion og det offentlige rum. Det er interessant at notere sig, at sekulariseringsteser i Vesten delte nogle store teoretikere. Durkheim og Weber delte ikke det sædvanlige teleologiske syn på modernitet, og de støttede især ikke overførelse af en sådan modernitet til ikkevestlige samfund. Da disse teorier tjente som grundlag for modernitet, tjente de også som grundlag for vestliggørelse og blev udvidet til også at danne basis for universalisme. Sekulariseringsessens blev ensbetydende med religion som en forhindring for moderne udvikling universelt.

Da de ikke-vestlige samfund dannede deres egne nationalstater, overtog de blindt den vestlige opfattelse, at religionen skulle holdes 'isoleret' og ikke afspejles i disse samfunds kulturelle særegenheder.

Et slående eksempel på dette orientalistiske perspektiv vil være Tyrkiet, hvor nationens grundlæggere brændemærkede islam og dekreterede, at islam måtte inddæmmes for at skabe den moderne stat Tyrkiet.

Ikke-vestlige lande oplevede, at perioden under den kolde krig, der var domineret af supermagtsrivalisering, fulgte industrialiseringens vej, som da Jawharal Nehru, Indiens første premierminister, i parlamentet erklærede, at det primære imperativ var 'at hale ind' på både USA og Sovjetunionen. Trods anerkendelse af de store forskelle sagde han: "Disse to typer udvikling er grene på det samme træ".
Malaysias aktive promovering af 'asiatiske værdier' afspejlede også postkoloniale landes aspiration at projektere deres kulturelle særkende over for og imod Vesten. Denne moderniseringsproces gav rum for skabelse af identitet internt.

\section{Asiatiske værdier}

Som (professor i postkoloniale studier) Stephanie Lawson har påpeget, opererer promoveringen af asiatiske værdier som instrument til "at skabe et forenet, nationalistisk samlingspunkt - og til at differentiere det forenede 'os' til det ydre 'dem'”.

Identitetsspørgsmål fik en mindre rolle, da nationsdannelse tog vejen til at være moderne, som blev set som synonymt med at være industrialiseret. Man kan selvfølgelig argumentere for, at identitetsspørgsmålet, selv om dets mange lag altid var til stede, viste sig, da nyligt udviklede lande forsøgte at skabe sine 'distinkte' identiteter vis-a-vis de andre igennem at udvikle en 'national' fortælling.

Men med afslutningen på den kolde krig og især med 'krigen mod terror' dukkede debatten om identitet igen helt op til overfladen, spørgsmålet om hvorvidt alle moderne nationer skulle være 'vestlige' på alle måder eller genoplive og bevare deres egen kulturelle særkender, der ofte var forbundet med religionsudøvelse og symbolik.

Islams renæssance på den politi- 
ske arena kan spores til arabernes nederlag til Israel under seksdages krigen, oliekrisen i 1973 eller den mere berygtede iranske revolution i 1979.

\section{Arabisk forår}

Det arabiske forår, der begyndte at ryste Mellemøsten fra december 2010, blev først set som oprør imod længe herskende islamiske autokrater i regionen. Det efterfølgende sammenbrud for regimer og tilbagegreb til demokrati efterlod verden forundret, da regeringer i Tunesien og Egypten blev dannet af folkevalgte islamistiske grupper. Mange spurgte sig nu, hvad handler det arabiske forår overhovedet om?

Det har været set af mange kommentatorer som en måde at genvestliggøre verden via oprørets omfavnelse af vestlige idealer om demokrati. Men i stedet banede disse demokratiske optioner vejen for, at islamistiske politiske partier kunne komme til magten med fredelige midler.

Før det arabiske forår startede, skete det samme i Tyrkiet, hvor partiet AKP blev genvalgt med folkeligt mandat to gange og konsoliderede sit politiske greb om magten. Men genoplivelsen af islamister og deres folkelige støtte kan i stedet vise, at folk i disse lande - og måske mere generelt - er interesserede i en gradvis tilbagevenden til deres ideologiske rødder og sammensmeltnin- gen af disse med moderne kræfter, der er sat fri af demokratiske idealer. Men andre ord er modernisering ikke et eksklusivt resultat af vestliggørelse. I lande med muslimsk flertal tenderer modernisering i stedet til at sammenblande islam og modernitet.

Måske ønsker vi ikke at kalde det islamisk modernitet. Vi ønsker måske at anerkende både dens modsætningsfyldte natur og opfattelsen af, at forholdet mellem de to kan betyde fredelig sameksistens ved at referere til det som 'muslimer og modernitet'.

\section{Asiatisk identitet}

Som eksempel tjener projiceringen af malaysisk identitet $\mathrm{i}$ kølvandet på 9/11, hvor (tidligere regeringsleder) Dr. Mahathir Mohammad fremhævede "Malaysias status som magtfuld, disciplineret og lærd nation, som kan forsvare sig selv og islam".

Råbet om et forenet 'os' fremstår som en klar skillevej i den malaysiske oppositionsleder Anwars Ibrahims karriere. Han udviklede sig fra 'karismatisk fundamentalist' i 1980'erne til en 'liberal globalist', der gik ind for reformasi (reformer) sidst $\mathrm{i}$ 1990'erne.

Svaret fra især sydøstlige lande med muslimsk flertal på 9/11 fremmede skabelsen af sidestillingen mellem modernitet og islam som et vigtigt træk, som islamforskeren Lily 
Rahim har argumenteret for, "ved den lige behandling af alle religioner fra statens side samt religionsog samvittighedsfrihed".

En sådan opfattelse afviser orientalistiske opfattelser af islam som en forhindring for moderne udvikling. Lily Rahim argumenterer for, at et sådant skifte i islamiske lande var tydeligt under det arabiske forår i Mellemøsten og har defineret denne unikke manifestation af post-islamisme som 'refolution', en blanding af reformistiske og revolutionære mål.

I sin analyse af den politiske udvikling post det arabiske forår, har Rahim argumenteret for, som også forskning synes at vise, at disse lande på en og samme tid har afvist den autoritære islamiske stat og autoritære sekulære principper i bestræbelse for at blande modernitet med kulturelle kendetegn for muslimske samfund.

\section{Tyrkiet, Egypten, Bangladesh}

Eliterne i disse tre lande synes at være ret upåvirkede af det faktum, at islam kan sameksistere i det offentlige rum, så længe religionen ikke bruges som et politisk våben. Det, som startede i Tyrkiet som en protest imod et udviklingsprojekt i Gezi Parken, eskalerede snart til en anklage mod den islamistiske regering for at kapre Tyrkiets sekulære identitet. Det, som startede i Bangladesh som en retssag imod krigsfor- brydere, blev snart 'sekulært' med de progressive eliters latterliggørelse af islam. En demokratisk valgt regering blev sat fra magten i Egypten, fordi den ville etablere totalitær kontrol med samfundet.

\section{Inddæmme islamister}

Mens de politiske situationer i disse tre lande kan synes uden politisk sammenhæng, ligger der til grund for alle tre scenarier et intenst ønske om at inddæmme islamister og dermed opnå 'moderne' troværdighed ved at reorientere islam efter basalt set vestlige perspektiver.

Når som helst at demokratiske rum er åbnet op, har mennesker været ivrige efter at vælge ledere, der tilbyder bedre løsninger på deres problemer, men som også kan tilbyde dem anerkendelse af deres kulturer.

Svaret på det er splittelsen mellem masserne og deres politiske eliter som ikke kun kan blive dybere. For eliterne har også valgt at gribe til repressive metoder for at kvæle udfordrerne. Bangladesh regeringens adfærd imod islamisterne var et slående eksempel på det og førte til fængslingen af den kendte menneskeretsaktivist, Adilur Rahman Khan, der blev anklaget for et antal dræbte under demonstrationer.

Og det virkelige antal døde forbliver omdiskuteret efter det egyptiske militærs nedkæmpelse af islamisterne i august 2013. 


\section{Politisering}

Den basale forståelse af sekularisme er måske 'tabt i oversættelsen' på globalt plan, både i Vesten og ikkeVesten og især i lande med muslimsk flertal. Sekularisme opstod ud af den indbyggede intolerance imellem katolikker og protestanter, men førte til den gensidige tilpasning og tolerance over for religiøse forskelle. Men, som det har udviklet sig, er det i stedet blevet til at identificere religion i sig selv som problemet for udvikling af modernitet og fornuft.
En sådan politisering af sekularisme har medført intolerance og politiske fejder, som må gentænkes, ikke bare i lande med muslimsk flertal, men også i de europæiske lande, hvor det er blevet forbudt at udtrykke sig selv med religiøst antræk i offentlige institutioner.

Lailufar Yasmin er lektor i Internationale Relationer ved Dhakas Universitet, Bangladesh. Hun forsker i bl.a. sekularisme og islam.

Oversat fra engelsk af Vibeke Sperling. 